\title{
Hieronymi Fracastorii: the Italian scientist who described the "French disease"
}

\author{
Filippo Pesapane ${ }^{1,2}$ \\ Gianluca Nazzaro ${ }^{1,2}$
}

Stefano Marcelli ${ }^{2,3}$

DOI: http:/ / dx.doi.org/10.1590/abd1806-4841.20154262

\begin{abstract}
Girolamo Fracastoro was a true Italian Renaissance man: he excelled in literature, poetry, music, geography, geology, philosophy, astronomy and, of course, medicine to the point that made Charles-Edward Armory Winslow define him as "a peak unequaled by anyone between Hippocrates and Pasteur". In 1521 Fracastoro wrote the poem "Syphilis Sive de Morbo Gallico" in which was established the use of the term "syphilis" for this terrible and inexplicably transmitted disease, often referred to as "French disease" by the people of the time and by Fracastoro himself.
\end{abstract}

Keywords: Syphilis; History of Medicine; Dermatology; Infection control; Pathology

Hieronymi Fracastorii, or Girolamo Fracastoro, (1483-1553) was one of the most important people at the center of the intellectual scene of the early sixteenth century, not only for the famous poem "Syphils sive Morbus Gallicus" (1530), but also for its proposal for an alternative to the Ptolemaic astronomical system, developed a few years before the Copernican revolution, based on the renewal of homocentrism. ${ }^{1}$

Its importance in the history of medicine is due to its many natural and medical considerations, represented in "De sympathia et antipathia rerum", foreword to the "De contagione et contagiosis morbis et eorum curatione libri tres", which exposes an innovative theory of contagion. ${ }^{2}$

Fracastoro was a true Italian Renaissance man: he excelled in literature, poetry, music, geography, geology, philosophy, astronomy and, of course, medicine. $^{3}$

At the early age of 24 years old he became professor of logic and, soon afterward, of anatomy at the "Università di Padova" where he met Nicolas Copernicus (1473-1543), who entered the academy to study medicine in $1501 .{ }^{4}$
Pope Paolo III, in 1545, named Fracastoro doctor of the Council of Trent. In this role Fracastoro itself was determinant in moving the seat of the council from Trent to Bologna, due to an outbreak of typhus, a disease that was first described in his book "De Contagione et Contagiosis Morbis". ${ }^{2}$

However, it was another disease that made Fracastoro famous: at the beginning of the sixteenth century an unpublished and incurable epidemic was spreading wildly, affecting an alarming population. Five hundred years ago, in 1521, Fracastoro wrote the poem "Syphils sive Morbus Gallicus" in which was established the use of the term "syphilis" for this terrible and inexplicably transmitted disease, often referred to as "French disease" by the people of the time (Figure 1). Whilst this poem is filled with mythological allusions it affords a good clinical description of the origin, symptoms and treatment of the disease now known by the name Fracastoro gave to one of his poetical characters. ${ }^{5,6}$ The three-volume poem, written in hexameters, consists of 1300 verses and traces the origin of syphilis through two legendary stories. The first story illustrates the voyage of Cristoforo Colombo in

Received on 30.11.2014

Approved by the Advisory Board and accepted for publication on 27.01.2015

* Work performed at the Dermatology Unit, "Fondazione IRCCS Ca' Granda, Ospedale Maggiore Policlinico", Department of Medical-Surgical and Transplantation Physiopathology, University of Milan - Milan, Italy. Financial Support: None.

Conflict of Interest: None.

"Fondazione IRCCS Ca' Granda, Ospedale Maggiore Policlinico" - Milan, Italy.
University of Milan - Milan, Italy.

IRCCS Policlinico S. Donato - Milan, Italy.

C2015 by Anais Brasileiros de Dermatologia 


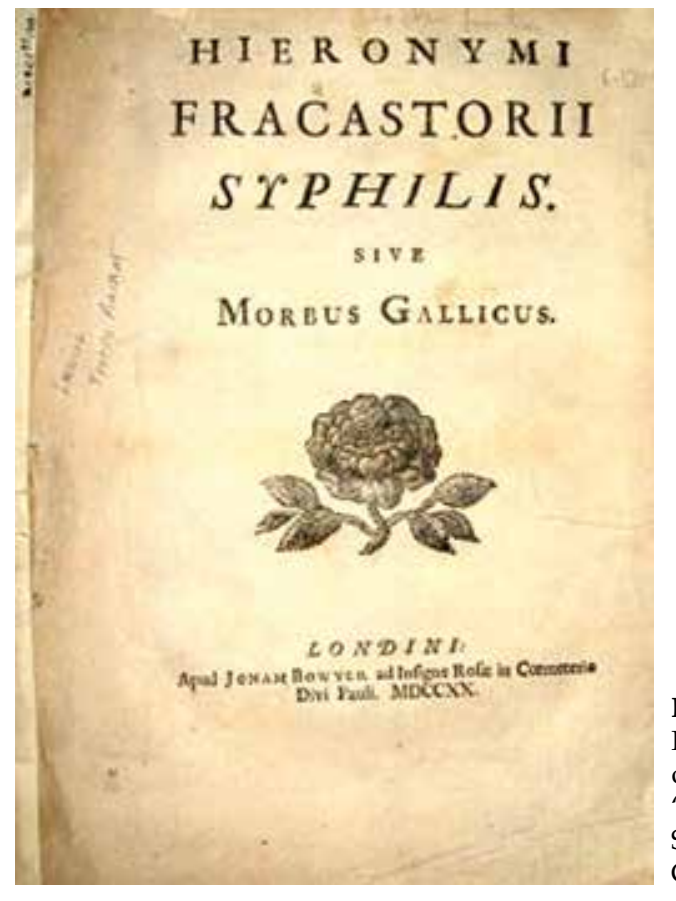

Figure 1: First page of the poem "Syphilis Sive Morbus Gallicus"

the West Indies, where the disease was overwhelming among the natives because of a curse from the gods of the lost city of Atlantis. It was in the West Indies that Colombo found out the holy guaiacum tree, whose extract could be used as an effective natural cure. ${ }^{7}$

According to the second legend the disease was originated and inflicted by Apollo, god of Sun, on Sifilo, who had become unfaithful to him. However Sifilo was cured by Juno, sister and wife of the chief god Jupiter, through the use of guaiacum. ${ }^{8}$

It is easy to see how such an interesting poem, combining practical medical skill with great ingenuity, should become deservedly popular. It went through very many editions, and has been translated into almost every European language. ${ }^{7}$

In 1546 Fracastoro published the treatise "De Contagione", which deserves similar recognition. In this book Fracastoro enunciated the modern doctrine of the specific character of fevers, the differentiation of typhus fever as a clinical entity and proposed that the infection resulted from tiny particles or "spores" that could be spread by direct or indirect contact, through infected objects or even without contact by long distance air dispersion. "De Contagione" made Fracastoro a pioneer of epidemiology and his theory remained highly influential for nearly three centuries, before being displaced by the germ theory. ${ }^{2}$

On August 6, 1553, Fracastoro suffered a stroke and expired the same day, in his villa at Incaffi, Italy. ${ }^{4}$

Most of the representations of Fracastoro seem to have been taken from the woodcut portrait in his "De Homocentricis" (Verona, 1538), which is supposed
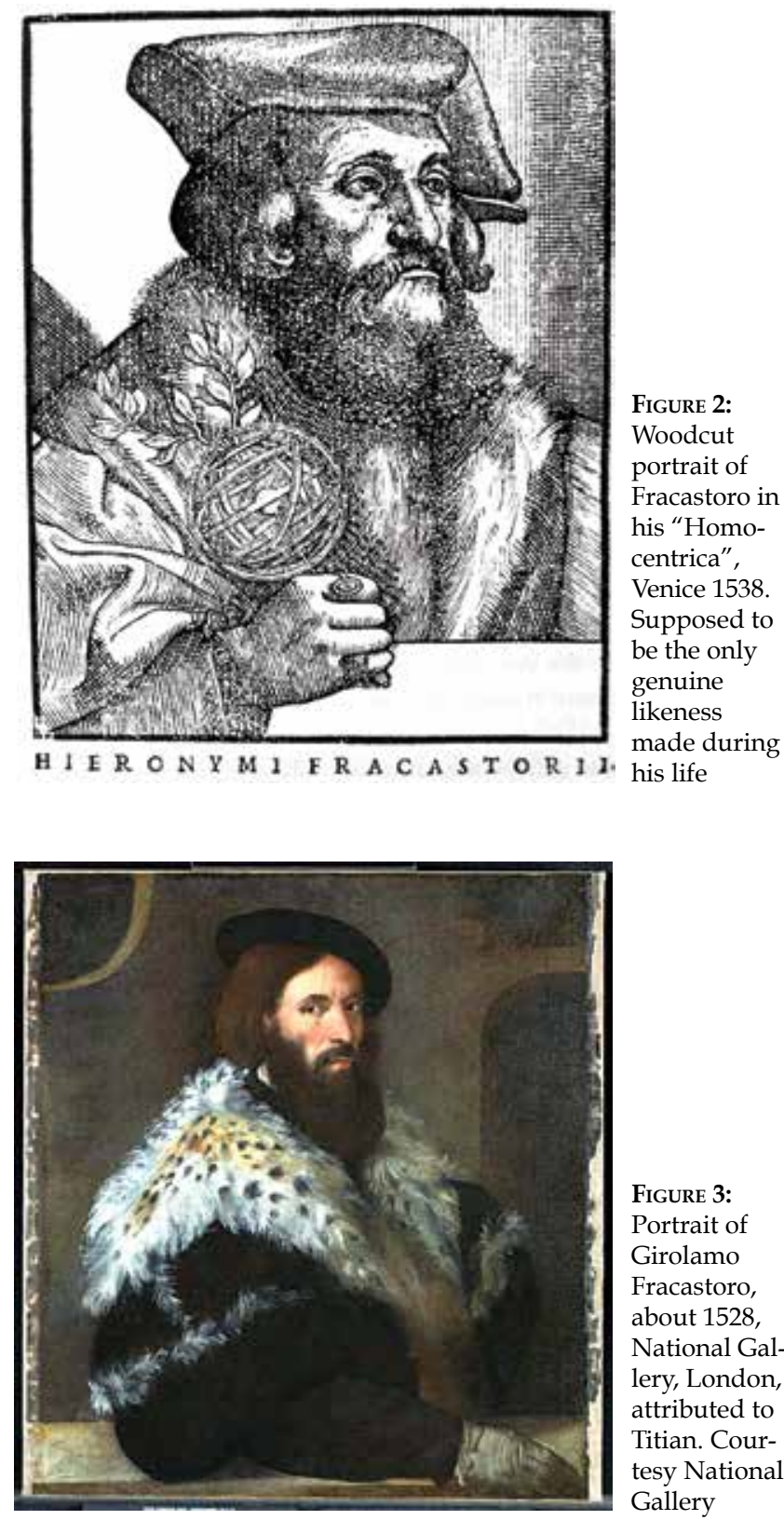

Figure 3:

Portrait of

Girolamo

Fracastoro,

about 1528,

National Gal-

lery, London, attributed to Titian. Courtesy National Gallery

to be the only authentic likeness made during Fracastoro's life (Figure 2). There is, however, a portrait in the National Gallery of London which is supposed to be that of Fracastoro: while it portrays a slightly younger man than the woodcut, there is a considerable similarity (Figure 3). Initially this painting was attributed to Francesco Torbido; according to recent investigations, however, it seems that the true author was the Venetian painter Tiziano. ${ }^{7}$

The National Gallery has owned this portrait of Fracastoro since 1924 and it was hung for years in a remote lower room, forgotten, but, finally, in 2013 it has been brought into the light of the main collection. It 


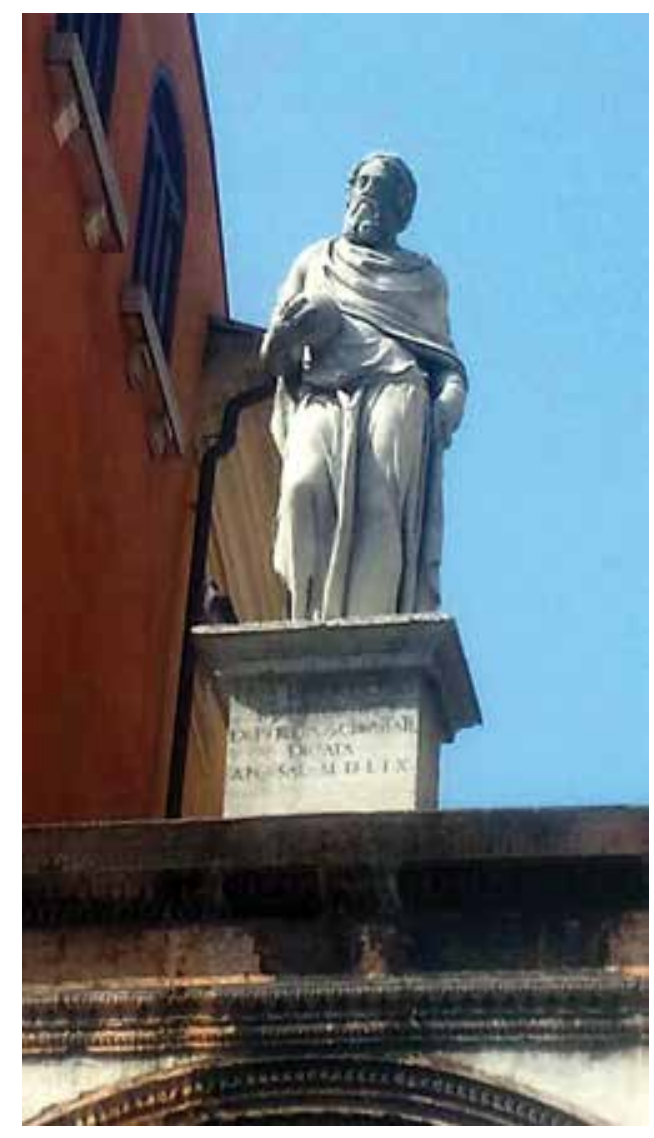

Figure 4:

Fracastoro statue in Verona, Italy was hypothesized that Tiziano painted the portrait of Fracastoro as compensation for being cured of syphilis, which it seems also affected the Venetian painter (Figure 3).

In memory of this great figure of the Italian Renaissance, in 1555 the Senate of Verona commissioned Danese Cattaneo to carve a life-size statue representing Fracastoro holding the world (idealized as a ball), which now adorns a narrow street arch near the Piazza dei Signori in the center of Verona (Figure 4). ${ }^{9}$ An old legend told at the time, when judges, lawyers, nobles and governors went to the old court passing by the statue, said that the "bala" (dialect word for ball) would have fallen on the first real gentlemen going across. People of Verona used this story to mock the governors of the city. Until today the ball remains firmly in its place.

\section{REFERENCES}

1. Singer C. Singer D. The Scientific Position of Girolamo Fracastoro. Annals Med. Hist. 1917;1: 1-34.

2. Fracastoro G, Wright WC. Hieronymii Fracastorii De Contagione, Libri III, Translation and notes. New York; London: G. P. Putnam's sons; 1930.

3. Winslow CEA. The Conquest of Epidemic Disease. Princeton, NJ: Princeton Univ. Press; 1943.

4. Peruzzi E, Fracastoro G. Dizionario biografico degli Italiani. Istituto della Enciclopedia Italiana, 49. vol., Roma; 1997.

5. Fracastoro G. Hieronymus Fracastor's Syphillis, from the original Latin, a translation in prose of Fracastor's immortal põem. St. Louis, Mo: The Philmar company; 1911.

6. Massalongo R, Fracastoro G. Girolamo Fracastoro e la rinascenza in Italia della medicina. Atti Ist. ven., LXXVI (1916-17). Venezia: C. Ferrari, 1915.

7. Stratman-Thomas WK. Girolamo Fracastoro and syphilis, Cal West Med. 1930;33:739-42.

8. Baumgartner L, Fracastoro G, Fulton JF. A bibliography of the poem "Syphilis sive morbus gallicus" by Girolamo Fracastoro of Verona. New Haven: Yale University Press; 1935.

9. Klebs AC. Iconographic Note on Girolamo Fracastoro. Bull Johns Hopkins Hosp. 1915;26: 378 .

\author{
MAILING ADDRESS: \\ Filippo Pesapane \\ Via Pace 9, Milan \\ 20145 - Italy. \\ E-mail: filippopesapane@gmail.com
}

How to cite this article: Pesapane F, Marcelli S, Nazzaro G. Hieronymii Fracastorii: the Italian scientist who described the "French disease". An Bras Dermatol. 2015;90(5):684-6. 